\title{
Planned Minimum Age of Subjects
}

National Cancer Institute

\section{Source}

National Cancer Institute. Planned Minimum Age of Subjects. NCI Thesaurus. Code C49693.

The anticipated minimum age of the subjects to be entered in a clinical trial. 